\title{
SEDIMENT FLUX AND EQUILIBRIUM SLOPES IN A BARRED NEARSHORE
}

\author{
BRIAN GREENWOOD and PETER R. MITTLER* \\ Departments of Geography and Geology, Scarborough Campus, University of Toronto, \\ Scarborough, Ont. M1C 1A4 (Canada) \\ Department of Geography, Scarborough Campus, University of Toronto, Scarborough, \\ Ont. M1C $1 A 4$ (Canada)
}

(Received April 18, 1983; revised and accepted July 31, 1983)

\begin{abstract}
Greenwood, B. and Mittler, P.R., 1984. Sediment flux and equilibrium slopes in a barred nearshore. In: B. Greenwood and R.A. Davis, Jr. (Editors), Hydrodynamics and Sedimentation in Wave-Dominated Coastal Environments. Mar. Geol., 60: 79-98.
\end{abstract}

Estimates of time-integrated values of total (ITVF) and net (INVF) sediment volume flux and the associated changes in bed elevation and local slope were determined for a crescentic outer nearshore bar in Kouchibouguac Bay, New Brunswick, Canada, for eight discrete storm events. A $100 \times 150 \mathrm{~m}$ grid of depth-of-activity rods spaced at $10 \mathrm{~m}$ intervals was used to monitor sediment behaviour on the seaward slope, bar crest and landward slope during the storms, at which time winds, incident waves and near-bed oscillatory currents were measured. Comparisons between storm events and between these events and a longer-term synthetic wave climatology were facilitated using hindcast wave parameters. Strong positive correlations between storm-wave conditions (significant height and total cumulative energy) and total volume flux contrasted strongly with the zero correlation between storm-wave conditions and net volume flux. ITVF values ranged up to $1646 \mathrm{~m}^{3}$ for the experimental grid and were found to have power function relations with significant wave height (exponent $\approx 2$ ) and cumulative wave energy (exponent $\approx 0.4$ ); values of INVF ranged from 0 up to $100 \mathrm{~m}^{3}$ for the same grid indicating a balance of sediment volume in the bar form through time. Sediment reactivation increased linearly with decreasing depth across the seaward slope and bar crest reaching maxima of $20 \mathrm{~cm}$ for the two largest storms; bed elevation, and thus slope, changes were restricted to the bar crest and upper landward slope with near zero morphological change on the seaward slope. The latter represents a steady-state equilibrium with null net transport of sediment under shoaling waves. Measurements of the asymmetry of orbital velocities close to the bed show that the energetics approach to predicting beach slope of Inman and Bagnold (1963) is sound. Gradients predicted vary from 0.01 to 0.03 for a range of angles of internal friction appropriate to the local sediment $(\tan \phi=0.3-0.6)$. These compare favorably with the measured seaward slope of 0.015 formed under average maximum orbital velocities of $1.12 \mathrm{~m} \mathrm{~s}^{-1}$ (landward) and $1.09 \mathrm{~m} \mathrm{~s}^{-1}$ (seaward) recorded during the period of the largest storm waves.

\footnotetext{
*Present address: Dasco Data Products, 304-8495 Ontario Street, Vancouver, B.C. V5X 3E8, Canada.
} 


\section{INTRODUCTION}

In many coastal environments dominated by waves the nearshore slope is characterized by one or more bars (Greenwood, 1982), which remain as stable bathymetric configurations throughout the annual cycle of wave climate (for example see Greenwood and Davidson-Arnott, 1975) and therefore appear in equilibrium with nearshore wave and current processes. However, the magnitude and frequency of occurrence of the sedimentation processes controlling bar growth and dynamics are still ill-defined and considerable debate continues concerning the mode and forcing of the sediment transport processes involved (Greenwood and Davidson-Arnott, 1979). Clarification of these issues requires knowledge of both fluid, sediment and morphological dynamics in the prototype over reasonably long periods to include especially periods of intense sediment transport. Furthermore, since the bar form consists of a very large number of slope facets each responding to local stresses, there is a need for knowledge of the spatial variability of process and form at this scale.

At the present time technological limitations prevent the necessary experiments to adequately answer the questions outlined above. However, recently it has been possible to obtain measures of both the sediment flux and bed elevation changes integrated over a storm cycle for a series of closely spaced locations within the nearshore zone (Greenwood and Hale, 1980; Greenwood et al., 1980). In this paper the sediment flux and morphological response in a nearshore bar is analysed for a series of storm-wave events of known frequency of occurrence and the data used to test one of the basic approaches to the prediction of local bed slope under wave activity.

\section{EQUILIBRIUM NEARSHORE SLOPES}

Currently no fully adequate theory of nearshore equilibrium exists although our general understanding of this equilibrium was well defined in the highly deductive and qualitative statement of Johnson as early as 1919:

"At every point the slope is precisely of the steepness required to enable the amount of wave energy there developed to dispose of the volume of sediment there in transit."

Even earlier Cornaglia (1898) had proposed a null point hypothesis emphasizing the concept of the balance of forces (wave-generated currents, gravity, inertia) controlling the stability of single particles on nearshore slopes. This theory was quantified and tested experimentally by Ippen and Eagleson (1955), Eagleson and Dean (1961) and Eagleson et al. (1963), but met with only limited success. Qualitative models of the nearshore slope as a balance between wave-induced transport of sand landward and a seaward return via rip-current activity (Grant, 1943; Cook, 1970; Greenwood and DavidsonArnott, 1979) have been supported by observation, but lack a quantitative form capable of being tested rigorously. Perhaps the most significant development in understanding coastal equilibrium under wave motion was that due 
to Inman and Bagnold (1963) based on Bagnold's $(1963,1966)$ energeticsbased bedload transport model originally derived for unidirectional flow. In this formulation a local slope of zero net transport develops at equilibrium as a result of a balance of forces induced by asymmetry in the on-offshore velocities, the angle of internal friction of the sediment and the tangential component of gravity controlled by the slope itself. In essence the slope was defined by the ratio of offshore to onshore energy dissipation under oscillatory flow and the angle of internal friction of the sediment:

$\tan \beta=\tan \phi\left(\frac{1-c}{1+c}\right)$

where $\tan \beta=$ beach slope; $\tan \phi=$ coefficient of internal friction; and $c$ is defined:

$c=\frac{\text { offshore energy dissipation }}{\text { onshore energy dissipation }}$

Thus, under shoaling waves, the increasing beach slope landward was a response to the increased total dissipation due to increased velocities at the bed and the relative difference in dissipation in the landward and seaward directions.

In 1979 the senior author proposed a conceptual model for equilibrium in nearshore bars whereby the seaward slope was maintained by the asymmetries in transport associated with the shoaling waves (Greenwood and DavidsonArnott, 1979). If such is the case, then the Inman and Bagnold relationship should provide a prediction of the nearshore slope in this zone, if the energy dissipation ratio can be measured or predicted. Inman and Frautschy (1966), following Bagnold (1963), proposed that the energy dissipation ratio, $c$, was proportional to the third power of the ratio of the relevant onshore and offshore orbital velocities:

$c=\left[\frac{U_{\mathrm{m}}-\text { offshore }}{U_{\mathrm{m}}-\text { onshore }}\right]^{3}$

where $U_{m}$ is the maximum orbital velocity. This is in fact a measure of asymmetry in the orbital velocity field. Support for the basic mechanisms suggested by Bagnold (1963) and Inman and Bagnold (1963) can be seen in more recent sediment transport models which have adopted this approach. In 1980 Bowen proposed a quantitative model for predicting equilibrium beach slopes, which included a consideration of both suspended and bed load under oscillatory flows. An attempt to incorporate the effects of longshore currents is seen in the transport model of Bailard $(1981,1983)$ and Bailard and Inman (1981).

It is not possible in this study to provide a test of these later models, but rather a simple evaluation of the basic energetics approach is made by testing the predictor equation for slopes proposed in the original formulation. 


\section{LOCATION}

The study was carried out in Kouchibouguac Bay, which is located at the western end of Northumberland Strait on the New Brunswick coast of Canada (Fig.1). Extensive detail on the form, structures, textures and bar dynamics, together with the general environmental constraints on the bar systems, have been documented previously (Greenwood and Davidson-Arnott, 1975, 1979; Davidson-Arnott and Greenwood, 1976; Greenwood and Hale, 1980) and only a brief synopsis need be presented here.

The area is a low-to-medium energy, micro-tidal (1.25 m maximum spring tide), storm-wave dominated environment, where sediment flux occurs as a highly discrete process during the passage of meteorological depressions (Greenwood and Hale, 1980). The nearshore bathymetry consists of a twobar system with local slopes typified by those illustrated in Fig.2. The inner system is planimetrically variable with straight, oblique and crescentic forms cut through by well defined rip channels in places. In contrast the outer bar is generally continuous and crescentic in character (average wavelength = $500 \mathrm{~m}$; average amplitude $=35 \mathrm{~m}$ ) and ranges in height from 1.5 to $2.5 \mathrm{~m}$. The outer bar, of particular relevance to this study is built in well-sorted, medium-to-fine sands (mean diameter $0.56^{--0.14} \mathrm{~mm}$ ). Furthermore, it is a

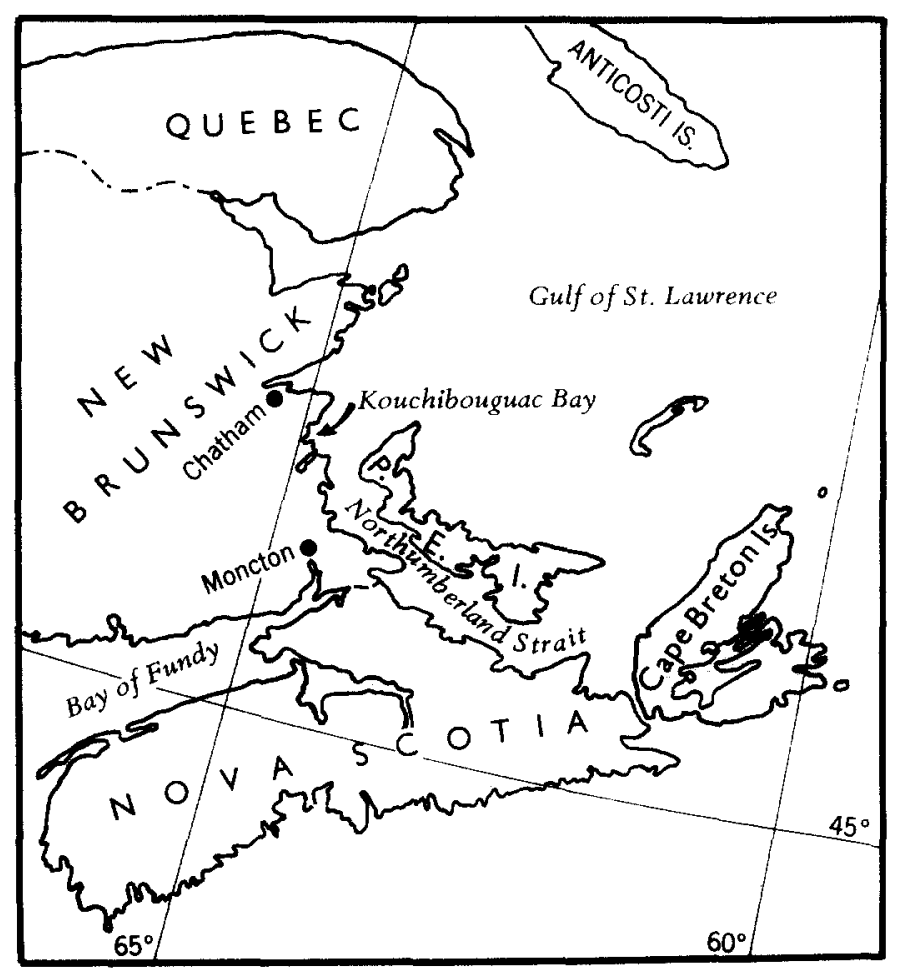

Fig.1. Location of study area. 


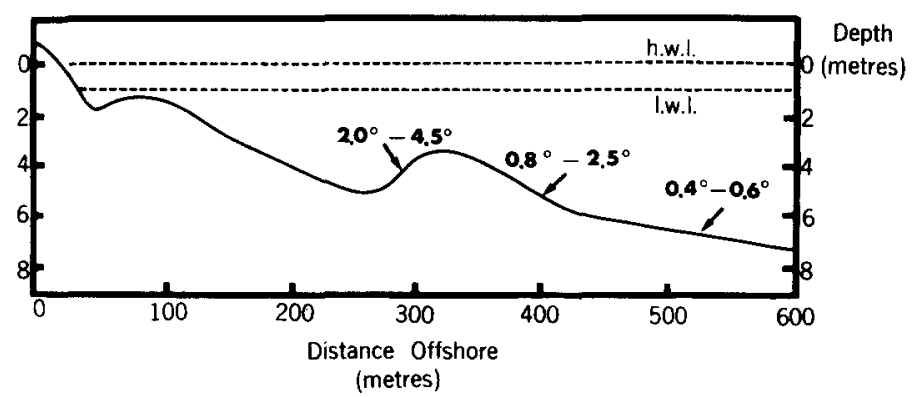

Fig. 2. Representative profile across the inner and outer bar systems of Kouchibouguac Bay.

highly stable feature in an environment of relatively high annual alongshore transport. Table I documents the sediment volumes and transports. It is clear that although large volumes of sediment exist in the bar system, collective transport alongshore due to bar migration contributes relatively little to the annual littoral drift.

A simple conceptual model of the equilibrium nature of these bars is based on a landward flux of sediments under asymmetric orbital motions due to waves, balanced by a seaward return of sediment in rip currents as part of a cellular nearshore circulation (Greenwood and Davidson-Arnott, 1979). Implicit to this hypothesis was that the seaward slope was essentially an equilibrium transport surface maintained by orbital asymmetries under the shoaling waves. Important questions therefore arise as to the mobility of the bar sediments (rates, spatial variability, relationship to wave energy, etc.), the morphological response to this mobility and the type of morphological equilibrium established (static, steady, dynamic, etc.). These will be addressed in this paper.

\section{TABLE I}

Sediment volumes and gross sediment flux Kouchibouguac Bay

\begin{tabular}{|c|c|c|}
\hline Source & Amount & \\
\hline $\begin{aligned} \text { Bar form: } & \text { Total bar } \\
& \text { : Per } m \text { length } \\
& : \text { Total bay }{ }^{2}\end{aligned}$ & $\begin{array}{l}\sim 2 \times 10^{5} \mathrm{~m}^{3} \\
\sim 4 \times 10^{2} \mathrm{~m}^{3} \\
\sim 6 \times 10^{6} \mathrm{~m}^{3}\end{array}$ & \\
\hline Net annual littoral drift ${ }^{3}$ & & $\sim 1 \times 10^{5} \mathrm{~m}^{3} \mathrm{yr}^{-1}$ \\
\hline $\begin{array}{l}\text { Collective transport by } \\
\text { bar migration } 4\end{array}$ & & $\sim 1 \times 10^{2} \mathrm{~m}^{3} \mathrm{yr}^{-1}$ \\
\hline
\end{tabular}

${ }^{1}$ Based on single crescentic unit, $500 \mathrm{~m}$ long, $1.5-3 \mathrm{~m}$ high; ${ }^{2} 15 \mathrm{~km}$ of bar; ${ }^{3}$ based on averaging dredging data, growth of inlet shoals and prediction based on CERC method $1973 ;{ }^{4}$ migration rate based on repeat surveys. 


\section{EXPERIMENTAL DESIGN}

At the present state of technology no satisfactory instrument exists for monitoring simultaneously both suspended and bedload, and the morphological changes associated with a net sediment flux, across any large area in the nearshore. In this study a simple device is used which gives a measure of sediment transport (total and net) as well as local changes in elevation of the transport surface. This depth-of-activity rod (Greenwood and Hale, 1980; Greenwood et al., 1980) is a simple adaptation of the vigil network erosion pin and can be deployed in numbers sufficient to cover large areas. It consists of a round steel rod $(0.5 \mathrm{~cm}$ diameter, $1-2 \mathrm{~m}$ in length) driven vertically into the sand by a Scuba diver until $0.45 \mathrm{~m}$ is left exposed; a loose fitting washer $(0.6 \mathrm{~cm}$ internal diameter) is placed over the rod and allowed to fall to the bed. The rod is tagged with a fluorescent streamer tape and stamped with an identifier to assist re-location. Figure 3 illustrates the pre- and poststorm measurements made by a Scuba diver. These measurements are used to make estimates of the sediment flux taking place through discrete periods of time, i.e. the duration of the storm event. Assuming that the changing washer location indicates the maximum depth of reactivation (see Greenwood and Hale, 1980, for tests), then the minimum total volume of sediment in transport is also given. Since the rod measurements are time-integrated estimates of this transport rate (i.e., a volume) through the local control volume, this has been termed the integrated total volume flux (ITVF). In a similar manner the bed elevation changes measured at each rod represent the net volume transports integrated over the storm duration (again a volume measure): this has been termed the integrated net volume flux (INVF). The depth of activity and bed elevation measures record the response of the local slope to wave activity at the storm peak and the total sediment transport event.

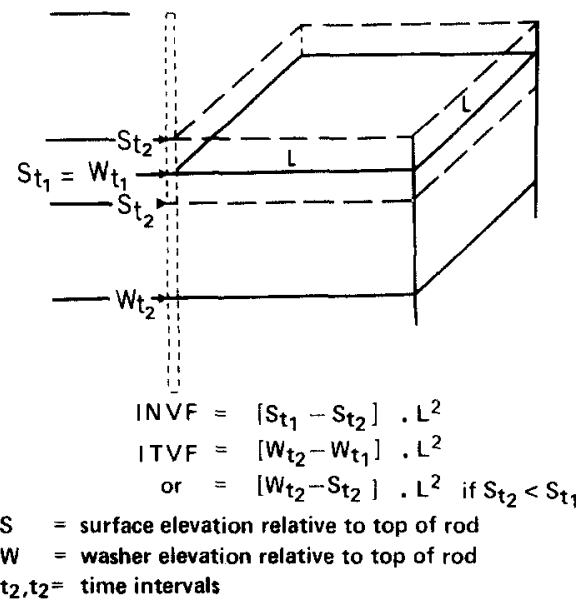

Fig. 3. Measurements made with the depth-of-activity rod and computations for sediment flux: $I T V F=$ time-integrated total volume flux, INVF = time-integrated net volume flux. Both $I T V F$ and $I N V F$ are volume measures. 
To measure sediment flux and bed elevation change across the outer bar system, a reference grid $(100 \times 150 \mathrm{~m})$ of depth-of-activity rods was established. Figure 4 illustrates the configuration of the grid, the primary rod coordinates and the relationship of the grid to a shore-normal profile. Rods were spaced at $10 \mathrm{~m}$ intervals and a subset was used to monitor the seaward slope. Control volumes for each grid were computed simply by extrapolating a line from the break-of-slope at the foot of the seaward slope to the trough and drawing vertical lines from the grid margins (Fig.5); a mean profile was assumed for the total grid to simplify calculations of these volumes potentially available for entrainment.

Fluid motions near the bed were recorded with an electromagnetic flowmeter (Marsh-McBirney Model 551) located in the centre of the seaward slope grid (Fig.4). The flowmeter sensor was mounted initially $0.2 \mathrm{~m}$ above the bed; however, depth of activity and bed elevation changes indicated possible variations in height of the sensor during storms between 0.15 and $0.38 \mathrm{~m}$.

A continuous resistance wave gauge was deployed $700 \mathrm{~m}$ offshore in $7 \mathrm{~m}$ of water to record incident wave conditions, which provided a yardstick for storm magnitude. Winds, measured at the beach face with a Type $45 \mathrm{~B}$ Anemometer, were used to hindcast waves when direct measurements were unavailable. Hindcasting of waves using winds from the meteorological station at Chatham (Fig.1) allowed individual storms to be placed in the

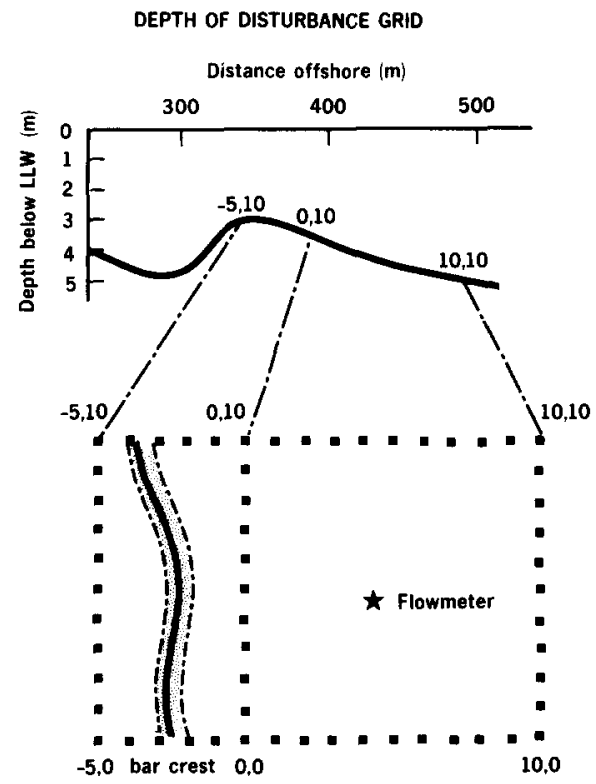

Fig.4. Deployment of experimental grids of depth of activity rods, Kouchibouguac Bay, 1977 and 1978. The 1977 grid was restricted to the seaward slope, row 0 to row 10 and this subset was used to monitor the seaward slope in both 1977 and 1978 . Note the location of the flowmeter. 


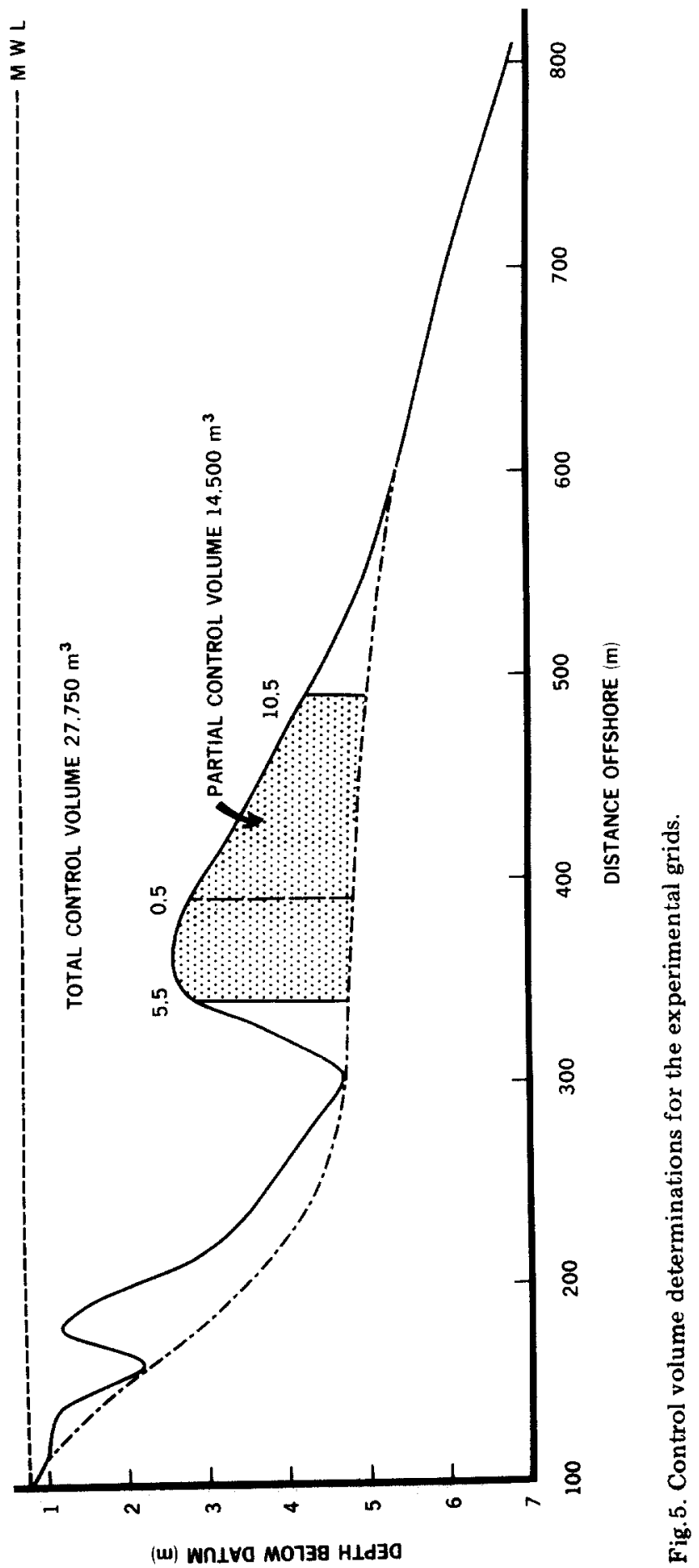


context of a synthetic wave climatology already established for the Bay (Hale and Greenwood, 1980). In this way the return periods and thus relative significance of the storms could be assessed.

Wave and current sensors were typically sampled at $2 \mathrm{~Hz}$ for periods of 5-7 min every hour during storms, with occasional record lengths up to $30 \mathrm{~min}$. Wave spectra were computed using the University of California Biomedical Computer Package BMD02T (Dixon, 1971) to determine characteristic wave height $\left(H_{\mathrm{mo}}=4 \times\right.$ standard deviation of the wave record) and peak period $\left(T_{\mathrm{pk}}=\right.$ period corresponding to the frequency of the maximum energy density). Flowmeter records were resolved to produce true flow vectors (speed and orientation) and scatterplots used to describe the oscillatory motion at a particular period of time.

\section{SEDIMENT FLUX AND EQUILIBRIUM SLOPES}

\section{Sediment flux}

Table II summarizes data on the primary wave parameters and sediment flux for eight discrete storm events during 1977 and 1978, and reveals quite clearly the nature of the sediment balance. Although the percentage of the control volume mobilized by a single storm is not large it is significant, ranging from 1 to $12 \%$ with grid average maxima of $0.3 \mathrm{~m}^{3}$ per square metre of seaward slope in absolute terms. However, the time-integrated net volume flux (INVF) is extremely small, being less than one percent of the control volume in all cases. Small net additions of sediment and small net losses of sediment occur in approximately equal numbers.

To evaluate the response of the system to events of differing magnitude, which could then be placed within a correct time perspective, the time integrated total volume flux (ITVF) values were plotted against both measured

\section{TABLE II}

Sediment flux during storm events over the outer bar (seaward slope), Kouchibouguac Bay

\begin{tabular}{llllllrll}
\hline Date & $\begin{array}{l}\text { Duration } \\
(\mathrm{h})\end{array}$ & $\begin{array}{l}H_{\mathrm{mo}} \\
(\mathrm{m})\end{array}$ & $\begin{array}{l}T_{\text {pk }} \\
(\mathrm{s})\end{array}$ & $\begin{array}{l}\text { ITVF } \\
\left(\mathrm{m}^{3}\right)\end{array}$ & $\begin{array}{l}\text { Percent* mobilized } \\
(\%)\end{array}$ & $\begin{array}{l}\text { INVF } \\
\left(\mathrm{m}^{3}\right)\end{array}$ & $\begin{array}{l}\text { Percent } \\
\text { change (\%) }\end{array}$ \\
\hline $1977: 07: 06$ & 8 & 1.30 & 6.4 & 661 & 5 & 110 & -0.8 \\
$1977: 07: 23$ & 11 & 1.17 & 6.0 & 319 & 2 & 36 & -0.2 \\
$1977: 08: 24$ & 15 & 1.00 & 5.5 & 208 & 1 & 20 & +0.1 \\
$1977: 08: 30$ & 17 & 1.06 & 5.3 & 182 & 1 & 61 & -0.4 \\
$1978: 05: 23$ & 5 & No data & 297 & 2 & 1 & 0 \\
$1978: 06: 01$ & 10 & \multicolumn{2}{l}{ No data } & 880 & 6 & 98 & -0.7 \\
$1978: 07: 01$ & 45 & 1.94 & 8.2 & 1734 & 12 & 29 & -0.2 \\
$1978: 07: 24$ & 17 & 1.61 & 7 & 1657 & 11 & 103 & +0.7 \\
& & & & Average & 5 & & -0.2 \\
\hline
\end{tabular}

*Estimated control volume $=14,500 \mathrm{~m}^{3}$. 
and hindcast wave data for each storm. Figure $6 a, b$ and $c$ illustrates double logarithmic plots of ITVF against both the maximum significant wave height $\left(H_{1 / 3}\right)$ generated during the storms and the cumulative energy density (hindcast) for the duration of the storms. Both wave height and cumulative energy density are used here to express two characteristics of the storm: the former is a measure of the maximum energy input per unit time, while the latter is indicative of the total work done during a storm.

Strong positive correlations are evident in all cases with the percentage of explained variance ranging from a low of $45 \%$ in the case of hindcast
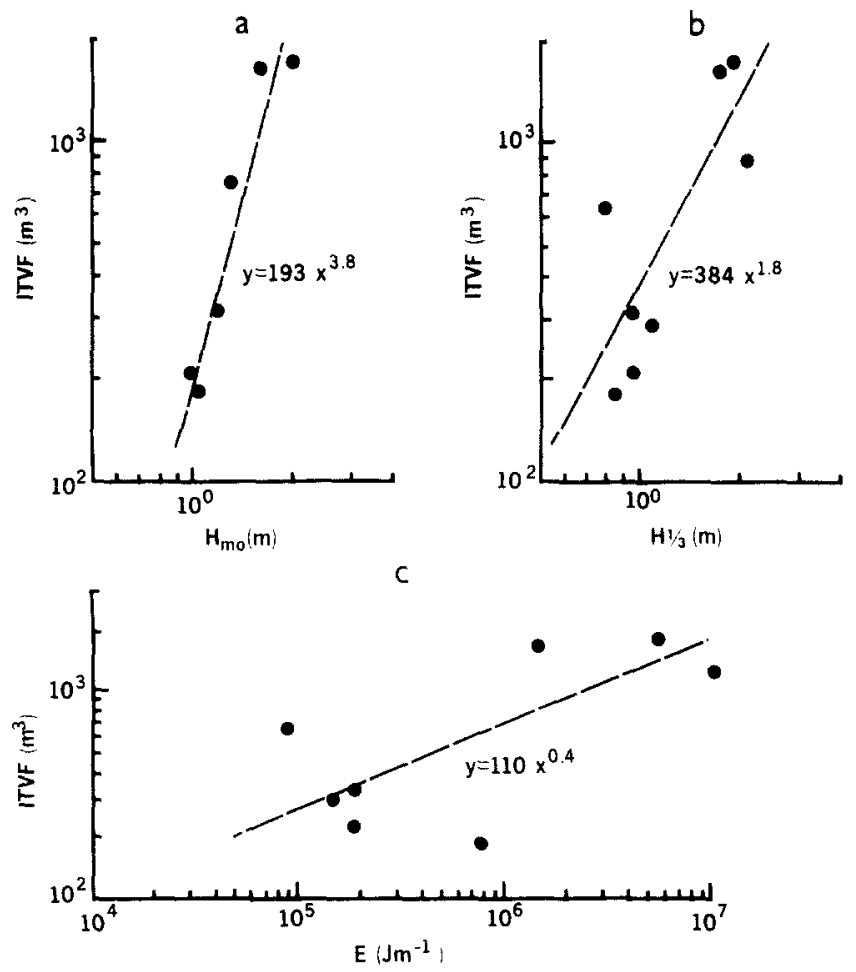

d

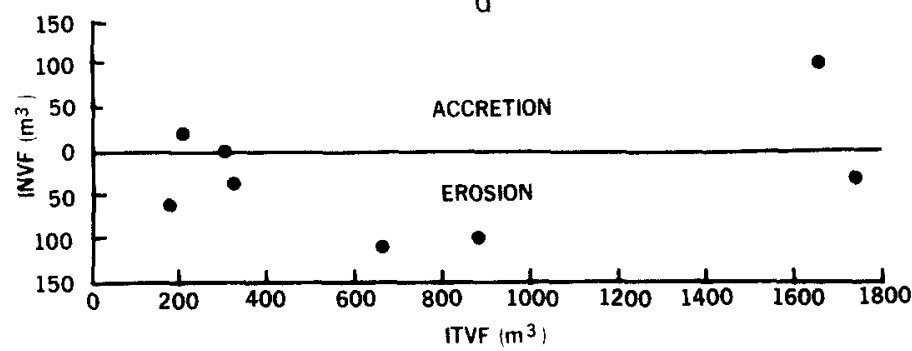

Fig. 6. Relationships between time-integrated total volume flux (ITVF), and (a) measured maximum significant wave height $\left(H_{\text {mo }}\right) ;(b)$ hindcast maximum significant wave height $\left(H_{1 / 3}\right)$; (c) hindcast cumulative energy density $(E)$; (d) time-integrated net volume flux (INVF). Values for discrete storm events are plotted. 
cumulative energy density to a high of $88 \%$ in the case of the measured significant wave height. Correlations with wave height are significant at the 0.05 level, while correlations with cumulative energy density are significant at the 0.10 level. The least squares regression lines suggest that a power function relationship exists between sediment response and wave energy. While it would be inappropriate to attach too great a significance to the absolute values of the exponents at this time it should be noted that sediment transport has always been considered as a power function of the forcing parameter. Indeed transport rates in the alongshore direction have been empirically established as being proportional to the square of the wave height (Galvin and Vitale, 1976). Certainly it is clear that the estimates of sediment reactivation are reasonably well recorded by the depth of activity rods and that maximum significant wave height is the better of the two wave parameters for predicting total sediment flux.

Of greater importance in the present context are the near-zero values for the INVF (Table II), even though the ITVF values range over an order of magnitude (Fig.6d). It would appear, therefore, that, at least in terms of sediment volume, the seaward slope exists in a state of steady equilibrium with the prevailing wave climate. If it can be established that the bar form remains stable both throughout storms and from storm to storm, then a steady morphodynamic equilibrium would be established.

\section{Spatial variability of sediment flux and bar morphodynamics}

Figure 7 illustrates the depths of activity and bed elevation changes for the two largest storms monitored (1978:01 and 1978:24). Table III documents the general storm characteristics. These two events had recurrence intervals close to $1.5 \mathrm{yr}$ based upon hindcast wave parameters and might be expected to indicate bar response to storms equal to that of the most probable annual maximum. Although differing in intensity to some degree it is evident that the sedimentary response was similar. In both cases maximum reactivation occurred on the bar crest with similar absolute values of 28 and $32 \mathrm{~cm}$; the average values for reactivation were also comparable (14 and $13 \mathrm{~cm}$ ). A general tendency for decreasing depth of activity with increasing water depth is also evident as might have been expected, but the seaward slope was subjected to considerable sediment motion even at its outer margin. It should be noted, however, that the data are somewhat "noisy" due to sampling variability, experimental error and variations in the bedforms generated. Bed elevation changes are some what less "noisy" overall and illustrate again a comparable response of the bar slope to the two storms. Large areas of the grid in both cases exhibit less than $\pm 1 \mathrm{~cm}$ change, which is close to the limit of measurement. Changes that do occur are more prevalent on the landward side of the bar crest and the landward slope; the seaward slope in contrast remained essentially stable in both cases even though large volumes of sediment were in motion. In order to generalize the shore-normal variability in the two measured parameters, grid row averages were calculated: 

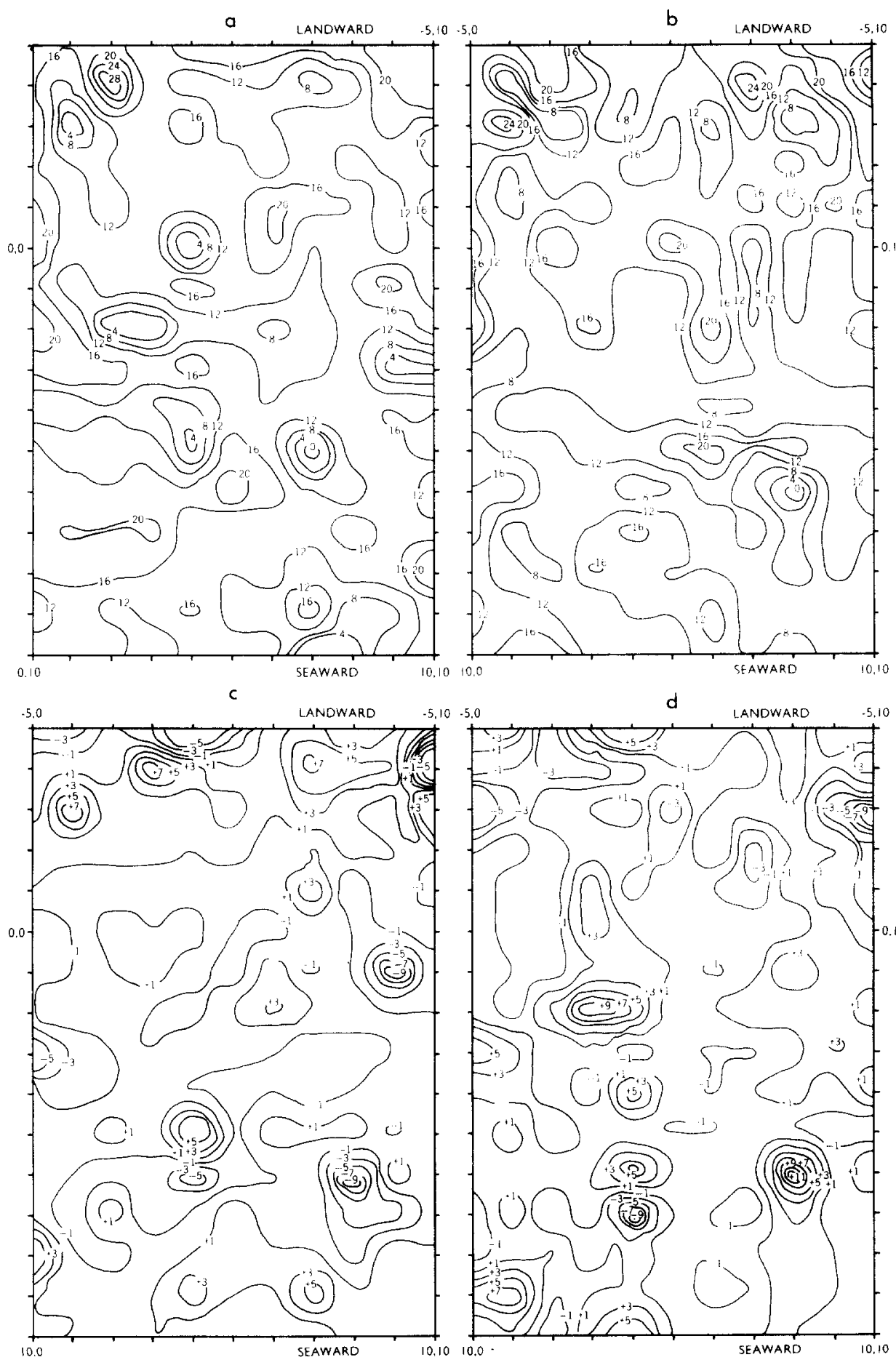

Fig. 7. Spatial distribution of depth of activity ( $a$ and $b$ ) and bed elevation change (c and d) over the outer bar during the storms of 1978:07:01 ( $a$ and $c$ ) and 1978:07:24 (b and $d$ ). Contours are at $4 \mathrm{~cm}$ intervals ( $a$ and $\mathrm{b}$ ) and $2 \mathrm{~cm}$ intervals ( $\mathrm{c}$ and d). The grid coordinates are check marked along the edges. 
TABLE III

Peak storm characteristics Kouchibouguac Bay, 1978:07:01 and 1978:07:24

\begin{tabular}{|c|c|c|c|c|}
\hline \multirow[t]{3}{*}{ Storm characteristics } & \multicolumn{4}{|l|}{ Storm event } \\
\hline & \multicolumn{2}{|l|}{$1978: 07: 01$} & \multicolumn{2}{|l|}{$1978: 07: 24$} \\
\hline & Measured & Predicted & Measured & Predicted \\
\hline Maximum wind speed & $58 \mathrm{kph}$ & $32 \mathrm{kph}$ & $48 \mathrm{kph}$ & $26 \mathrm{kph}$ \\
\hline Wind direction & $\mathrm{E}$ & $\mathrm{NE}$ & $\mathrm{NE}$ & $\mathrm{N}$ \\
\hline Wind duration & $45 \mathrm{~h}$ & $37 \mathrm{~h}$ & $17 \mathrm{~h}$ & $23 \mathrm{~h}$ \\
\hline Characteristic wave height $\left(H_{\text {mo }}\right)$ & $1.94 \mathrm{~m}$ & $0.72 \mathrm{~m}$ & $1.64 \mathrm{~m}$ & $0.62 \mathrm{~m}$ \\
\hline Characteristic wave period $\left(T_{\mathrm{pk}}\right)$ & $8 \mathrm{~s}$ & $4 \mathrm{~s}$ & $7 \mathrm{~s}$ & $3.2 \mathrm{~s}$ \\
\hline Maximum orbital velocity* & $1.26 \mathrm{~m} \mathrm{~s}^{-1}$ & - & $1.20 \mathrm{~m} \mathrm{~s}^{-1}$ & - \\
\hline Average orbital velocity* & $0.42 \mathrm{~m} \mathrm{~s}^{-1}$ & - & $0.39 \mathrm{~m} \mathrm{~s}^{-1}$ & - \\
\hline Recurrence interval**: $H_{1 / 3}$ & $1.45 \mathrm{yr}$ & $(0.14 \mathrm{yr})$ & $1.3 \mathrm{yr}$ & $(0.10 \mathrm{yr})$ \\
\hline$: \Sigma E$ & $1.1 \mathrm{yr}$ & $(0.40 \mathrm{yr})$ & $1 \mathrm{yr}$ & $(0.20 \mathrm{yr})$ \\
\hline
\end{tabular}

*Determined from resolved flowmeter vectors; sample period $5 \mathrm{~min}$.

**Figures determined from both the annual maximum series and, in parentheses, the partial duration series of storm wave predictions.

this gave an overall view of the sedimentary responses along a profile by reducing much of the "noise" in the data. Figure 8 illustrates these data and confirms that:

(a) As waves shoal and orbital velocities near the bed increase so there is an increase in the rates of sediment motion. An almost linear increase in the depth of activity is suggested here which follows the almost linear seaward slope. Although there is a slightly greater variation associated with the larger of the two storms there appears to be no difference in the average response of sediment transport. This is reasonable in that although measured wave heights were greater in the July 1 storm, the near-bed currents measured on the seaward slope were almost the same (Table III).

(b) With the reduction in orbital velocities as a result of height loss through breaking on the bar crest and with the increase in water depth, the lower landward slope and trough experienced reduced rates of sediment motion. Again a linear decrease in the depth of activity is suggested down the landward slope.

(c) In general bed elevation and thus slope changes on the seaward slope are extremely minor even under intense sediment reactivation by the shoaling waves. Most of the variability in the averaged values is less than $\pm 1 \mathrm{~cm}$.

(d) The bar crest and landward slope experience the greatest redistribution of sediment and morphological change. This is to be expected since these areas are subject to wave breaking and wave reformation with high orbital velocities and strong flow asymmetries. Intense turbulence and interactions between waves and secondary flows, such as seaward flowing rip currents, are common. In the July 1 storm it appears that on average the bar was shifted seaward with erosion of the landward slope and accretion on the bar 


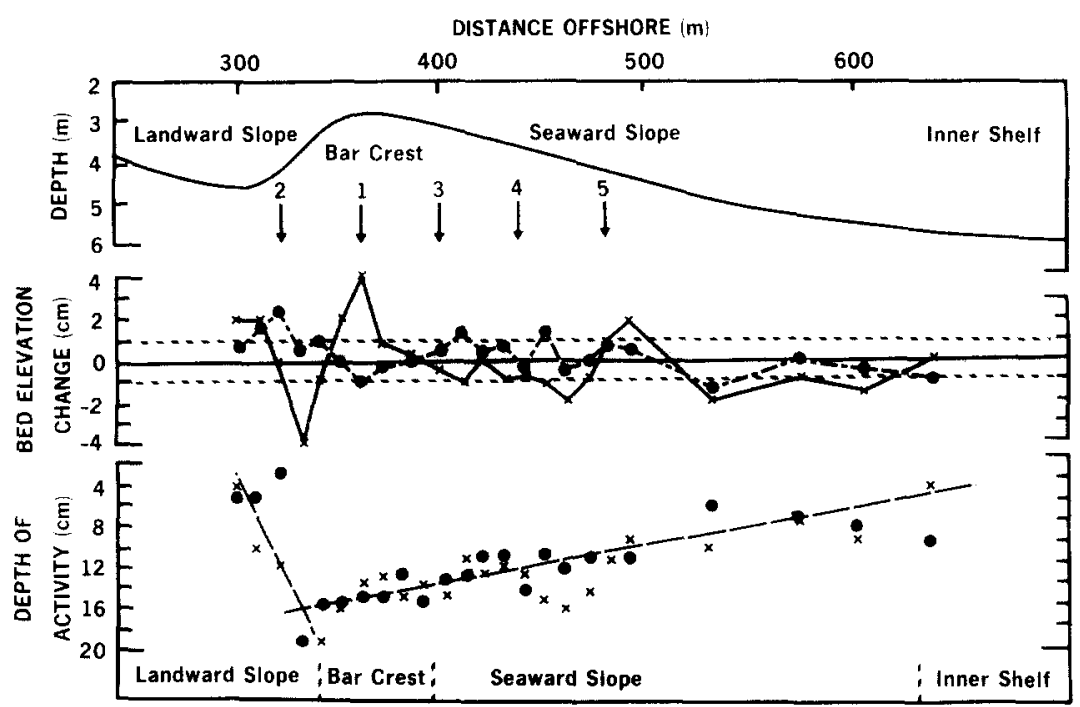

Fig.8. Average depth of activity and bed elevation change for the storms of 1978:07:01 (crosses) and 1978:07:24 (dots) across the outer bar. The profile is that taken along the centre line of the grid on 1978:07:14. The numbered arrows indicate locations of box cores.

crest: in the following storm of July 24 , with only slightly lower wave heights, accretion on the landward slope and thus landward migration of the bar was the average condition. It should be stressed that these are averages, since along a $100 \mathrm{~m}$ length of bar crest re-orientation of the crest location could produce landward migration in one section and seaward migration in another. This has been observed frequently on these bars (Greenwood and DavidsonArnott, 1975) with the crest oscillating about some mean position in association with the slow alongshore migration of the crescentic form and the transient positions of seaward flowing rip currents.

Two important aspects of the sediment flux patterns during these storms cannot, however, be addressed directly with the depth of activity rod data. The paths of net transport associated with bed elevation changes are not expressed, for example, nor is it possible to say whether the morphologically stable seaward slope is maintained by high but uniform rates of transport or whether a true oscillating equilibrium exists in the sediment transport. Examination of sedimentary structures preserved in the reactivated layer can provide some indication of transport paths (Greenwood and Davidson-Arnott, 1975; Davidson-Arnott and Greenwood, 1976; Greenwood and Mittler, 1979; Greenwood and Hale, 1980) as in the case of the 1978:07:24 storm. Epoxy peels of box cores from the bar crest and upper landward slope along the central profile (locations 1 and 2 in Fig.8) of the experimental grid all exhibit strong landward dipping cross-stratification indicative of landward migrating lunate megaripples (Fig.9a and b). This would suggest that the accretion of the landward slope indicated by the depth of activity rods results from 
sediment transferred landward from the crest where the rods suggest some slight degradation (Fig.8). Cores from the bar crest for a distance of 90 and $120 \mathrm{~m}$ either side of the grid all reveal similar structures supporting both a general transfer of sediment and a displacement of the bar in a landward direction (Mittler, 1981). Structural indices from the reactivation layer of the morphologically stable seaward slope (locations 3 and 4 in Fig.8) reveal a preponderance of planar stratification (Fig.9c and $\mathrm{d}$ ). Thus the high sediment transport indicated by the depth of activity and the near-zero net sediment flux indicated by the bed elevation change were associated primarily with sediment motion under flat bed conditions: no directional information is provided by these structures but continuity considerations would suggest that during the phase of high transport rates the sediment was likely in a state of near oscillating equilibrium rather than one of high uniform net transport.

The most striking aspect of these data is, however, the morphological stability of the seaward slope with high rates of sediment motion. This clearly supports the thesis that this unit is a surface of null net transport and thus in a state of steady equilibrium with the orbital velocity field associated with the shoaling waves.

\section{Seaward slope equilibrium}

From the preceding analysis it would seem that a balance of forces involving wave energy dissipation and the morphological gradient in the manner suggested by Inman and Bagnold (1963) would be appropriate to explain the steady state of the seaward slope of the bars in Kouchibouguac Bay. To test this theory, measured orbital velocities on the seaward slope were analyzed. In order to satisfy constraints imposed by the model, the flow field must be: (1) solely the result of the onshore-offshore motion of waves approaching along the shore-normal (line of maximum topographic gradient); (2) be representative of the lower boundary layer; and (3) great enough not only to produce motion but to ensure transport under flat bed conditions since, as was pointed out by Inman and Bowen (1962), transport over rippled beds under oscillatory flow produces a complex phase-dependent process involving suspension associated with vortex generation. Indeed, as the basic model requires bedload transport, a flat bed sheet flow model would seem most appropriate.

Current records were obtained from a number of the storms (Mittler, 1981), but in only one case did the velocity field satisfy the above mentioned criteria. Figure 10 illustrates this velocity field, recorded on July 1 at the peak of the largest storm monitored. The ellipses represent the limits of the distribution of current vectors determined from the electromagnetic flowmeter records. The principal axes of the ellipses, determined by least squares, illustrate the shore-normal approach of the waves at this time, the strength of the wave oscillations, and, most importantly, the landward asymmetry of the maximum orbital velocities. During other storms, either the wave 

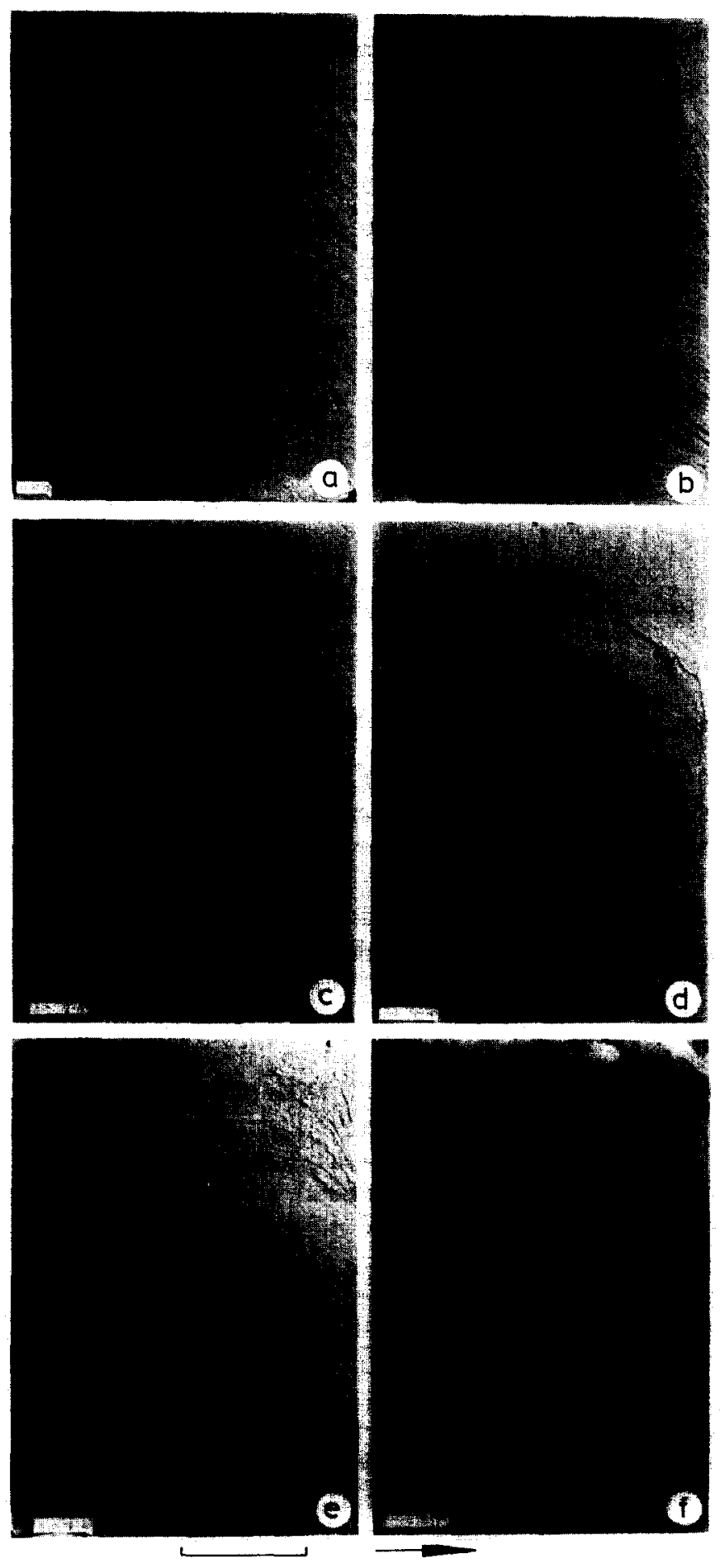


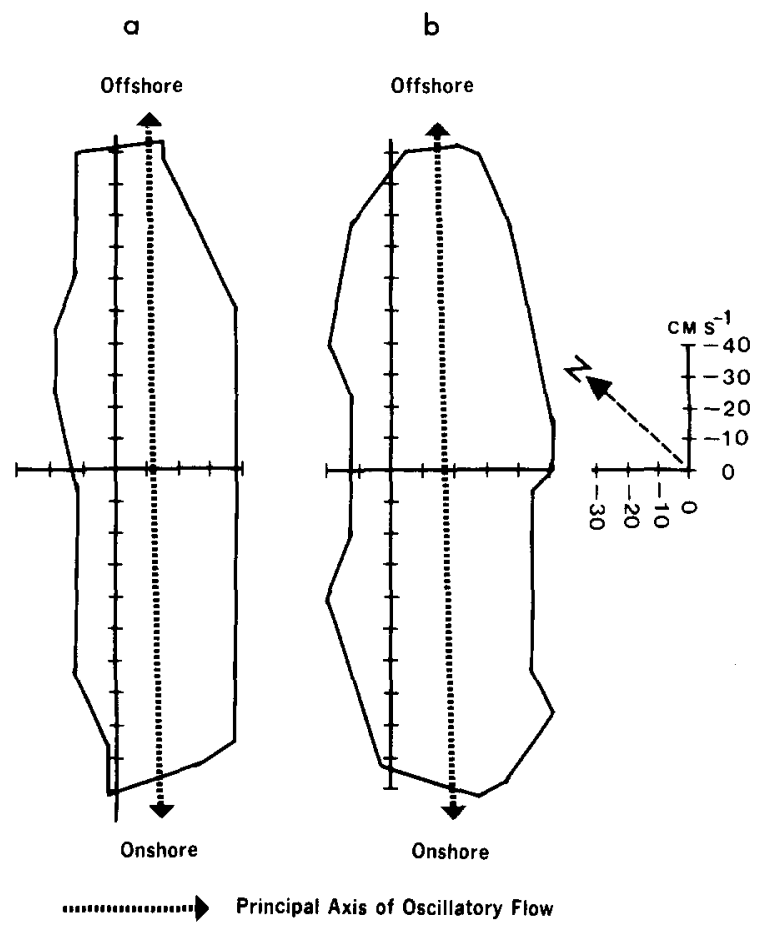

Fig. 10. Elliptical distribution of near bed flow vectors on the seaward slope of the outer bar, Kouchibouguac Bay, during the peak of the storm, 1978:07:01; (a) $1520 \mathrm{~h}$, (b) $1627 \mathrm{~h}$.

approach (and thus the primary orbital velocity vector) was not normal to shore, or the measured maximum offshore orbital velocity was greater than its onshore equivalent. Even with the very strong shore-normal currents of the July 1 storm, a slight displacement of the centroid of the ellipse suggests a superimposed shore-parallel flow (Fig.10). Detailed analysis of similar offsets in a large number of discrete flowmeter records shows such flows to be of tidal origin (Mittler, 1981). For sand of the size common on the seaward slope (mean diameter $\sim 0.18 \mathrm{~mm}$ ), even the mean orbital velocities (Table III) at this time would theoretically produce flat bed. Using the criterion of Dingler (1974) as expressed by Clifton (1976) for the transition velocity between rippled and flat bed this grain size would require a velocity of $\simeq 0.26 \mathrm{~m} \mathrm{~s}^{-1}$. This is far exceeded by the mean velocities measured and would indicate flat bed sediment transport at this time. Corroboration for this is provided by post-storm box cores from the seaward slope (locations 4 and 5

Fig.9. Epoxy peels of box cores and the associated depths of activity (in parentheses) after the storms of 1978:07:24 (a, b, c, d) and 1978:07:01 (e,f). The horizontal bar is $0.10 \mathrm{~m}$; the arrow indicates the direction of the shoreline. (a) bar crest $(0.15 \mathrm{~m}) ;(\mathrm{b})$ upper landward slope $(0.15 \mathrm{~m}) ;(\mathrm{c})$ upper seaward slope $(0.13 \mathrm{~m}) ;(\mathrm{d})$ mid-seaward slope $(0.14 \mathrm{~m})$; (e) mid-seaward slope $(0.13 \mathrm{~m})$; (f) lower seaward slope $(0.13 \mathrm{~m})$. 
in Fig.8) which illustrate dominance of planar stratification in the most recent active layer ( $F i g .9 e, f)$.

Table IV documents the maximum onshore and offshore velocities, the ratio of offshore to onshore energy dissipation as defined by Inman and Frautschy (1966) and the predicted equilibrium beach slopes for a range of values of the angle of internal friction appropriate to the sand materials present. Also given is the average slope along the profile measured after the storm from a position $10 \mathrm{~m}$ landward to a position $10 \mathrm{~m}$ seaward of the flowmeter location. From the earlier analysis of the depth of activity it is evident that differences in bed elevation would not have exceeded $2 \mathrm{~cm}$ even at the storm peak over this section of slope and this could have no effect on the slope value used in this comparison. Predicted slope values are given for both the maximum instantaneous velocity recorded, and the average maximum velocity based on three discrete sample records spaced $1 \mathrm{~h}$ apart during the storm peak. The correspondence between measured and predicted values is good, particularly, if the average maximum velocity for the storm peak is used. The latter is a more reasonable figure to use for sediment transport in any case, since transport is a time integrated phenomenon; further, the instantaneous maxima in a record could be the result of single waves.

\section{CONCLUSIONS}

Time-integrated values of total sediment flux over a large outer crescentic bar in Kouchibouguac Bay, Canada, were found to be positively correlated with measured and predicted wave energy parameters: power function relationships with exponents of $\sim 2$ to $\sim 4$ for significant wave height and $\sim 0.4$ for cumulative energy values provide statistically significant explanation. Time-integrated values of net sediment flux, in contrast, were close to zero and bear no relationship to the total reactivation of sediment. Local bed elevation changes were only significant over the bar crest and landward slope, with the seaward slope existing in a state of steady equilibrium with the wave processes. Continuity considerations suggest a state of oscillating equilibrium for the large

\section{TABLE IV}

Measured maximum orbital velocities, dissipation coefficients, predicted and measured nearshore slopes, Kouchibouguac Bay, 1978:07:01

\begin{tabular}{lllll}
\hline $\begin{array}{l}\text { Maximum orbital velocity } \\
\left(u_{\mathrm{m}}\right)\end{array}$ & $\begin{array}{l}\text { Dissipation coefficient } \\
(c)\end{array}$ & & $\begin{array}{l}\text { Nearshore slope } \\
\tan \beta\end{array}$ & \\
$\begin{array}{l}\text { Onshore } \\
\left(\mathrm{cm} \mathrm{s}^{-1}\right)\end{array}$ & Offshore & & $\begin{array}{l}\text { Predicted } \\
\tan \phi^{4}=0.300 .450 .60\end{array}$ & Measured \\
\hline $128^{1}$ & $123^{1}$ & 0.89 & 0.0180 .0260 .035 & $0.015^{3}$ \\
$112^{2}$ & $109^{2}$ & 0.92 & 0.0120 .0190 .025 & \\
\hline
\end{tabular}

${ }^{1}$ Maximum instantaneous velocity; ${ }^{2}$ average maximum during storm peak; ${ }^{3}$ average slope from post-storm survey ; ${ }^{4} \tan \phi=$ angle of internal friction. 
volumes of sediment set in motion on this slope by storm waves. Morphological changes on the bar crest and landward slope result from the number and variability of processes occurring here: asymmetric oscillatory currents associated with propagating surface gravity waves are present, but also turbulence associated with wave breaking and interactions between these and secondary longshore and rip currents.

Results of this study support both the basic energetics concept inherent in the Inman and Bagnold (1963) model for equilibrium nearshore slopes and the predictor equation based on the asymmetry in the maximum orbital velocities (Inman and Frautschy, 1966). Predicted values for the seaward slope of $0.012-0.025$ compare favourably with the measured value of 0.015 using measured average maximum orbital velocities of $1.12 \mathrm{~m} \mathrm{~s}^{-1}$ (landward) and $1.09 \mathrm{~m} \mathrm{~s}^{-1}$ (seaward), and a range for the appropriate angle of internal friction of $0.3-0.6$.

\section{REFERENCES}

Bagnold, R.A., 1963. Mechanics of marine sedimentation. In: M.N. Hill (Editor), The Sea, Vol. 3. Wiley-Interscience, New York, N.Y.

Bagnold, R.A., 1966. An approach to the sediment transport problem from general physics. Prof. Pap. 422-1, U.S. Geol. Surv., Washington, D.C., 37 pp.

Bailard, J.A., 1981. An energetics total load sediment transport model for a plane sloping beach. J. Geophys. Res., $86: 10,938-10,954$.

Bailard, J.A., 1983. Modeling on-offshore transport in the surfzone. Proc. 18th Coastal Engineering Conf., Cape Town, pp.1419-1438.

Bailard, J.A. and Inman, D.L., 1981. An energetics bedload model for a plane sloping beach: local transport. J. Geophys. Res., 86: 2035-2043.

Bowen, A.J., 1980. Simple models of nearshore sedimentation; beach profiles and longshore bars. In: S.B. McCann (Editor), The Coastline of Canada. Geol. Surv. Can., Pap. 80-10, pp.1-11.

Clifton, H.E., 1976. Wave-formed sedimentary structures: a conceptual model. In: R.A. Davis, Jr, and R.L. Ethington (Editors), Beach and Nearshore Sedimentation. Soc. Econ. Paleontol. Mineral., Spec. Publ., 24: 126-148.

Cook, D.O., 1970. Models for nearshore sand transport. Proc. 13th Conf. on Great Lakes Research, Buffalo, N.Y., pp. 210-216.

Cornaglia, P., 1898. On beaches. Accadamia Nazionale dei Lincei Atti, Classe di Scienze Fisiche, Matematiche e Naturali, Mem. 5, Ser. 4, pp.284-304. Reproduced in translation in: J.S. Fisher and R. Dolan (Editors), Beach Processes and Coastal Hydrodynamics. Benchmark Pap. in Geol., Stroudsberg, Pa., 39: 11-26.

Davidson-Arnott, R.G.D. and Greenwood, B., 1976. Facies relationships on a barred coast, Kouchibouguac Bay, New Brunswick, Canada. In: R.A. Davis, Jr. and R.L. Ethington (Editors), Beach and Nearshore Sedimentation. Soc. Econ. Paleontol. Mineral., Spec. Publ., 24: 149-168.

Dingler, J.R., 1974. Wave-formed ripples in nearshore sands. Unpubl. Ph.D. Diss., University of California, San Diego, Calif., $136 \mathrm{pp}$.

Dixon, W.J., 1971. BMD: Biomedical Computer Programs. University of California Press, Berkeley, Calif., $600 \mathrm{pp}$.

Eagleson, P.S. and Dean, R.G., 1961. Wave-induced motion of bottom sediment particles. Trans. Am. Soc. Civ. Eng., 126(1): 1161-1189.

Eagleson, P.S., Glenne, B. and Dracup, J.A., 1963. Equilibrium characteristics of sand beaches. J. Hydraul. Div. Am. Soc. Civ. Eng., 89(HY1): 37-57. 
Galvin, C.J. and Vitale, P., 1976. Longshore transport prediction - SPM 1973 Equation. Proc. 15th Coastal Engineering Conf., Honolulu, Hawaii, pp.1113-1148.

Grant, U.S., 1943. Waves as a sand transporting agent. Am. J. Sci., 241: 117-123.

Greenwood, B., 1982. Bars. In: M.L. Schwartz (Editor), Encyclopaedia of Beaches and Coastal Environments. Dowden, Hutchinson and Ross, Stroudsberg, Pa., pp.135-139.

Greenwood, B. and Davidson-Arnott, R.G.D., 1975. Marine bars and nearshore sedimentary processes, Kouchibouguac Bay, New Brunswick, Canada. In: J. Hails and A. Carr (Editors), Nearshore Sediment Dynamics and Sedimentation. Wiley, New York, N.Y., pp.123-150.

Greenwood, B. and Davidson-Arnott, R.G.D., 1979. Sedimentation and equilibrium in wave-formed bars: a review and case study. Can. J. Earth Sci., 16: 312--332.

Greenwood, B. and Hale, P.B., 1980. Depth of activity, sediment flux and morphological change in a barred nearshore environment. In: S.B. McCann (Editor), The Coastline of Canada: Littoral Processes and Shore Morphology. Geol. Surv. Can., Pap. 80-10, pp. 89-109.

Greenwood, B. and Mittler, P.R., 1979. Structural indices of sediment transport in a straight wave-formed nearshore bar. Mar. Geol., 32: 191-203.

Greenwood, B., Hale, P.B. and Mittler, P.R., 1980. Sediment flux determination in the nearshore zone: prototype measurements. In: Workshop on Instrumentation for Currents and Sediments in the Nearshore Zone, National Research Council of Canada, Associate Committee for Research on Shoreline Erosion and Sedimentation, Ottawa, Ont., pp. $99-120$.

Hale, P.B. and Greenwood, B., 1980. Storm wave climatology: a study of the magnitude and frequency of geomorphic process. In: S.B. McCann (Editor), The Coastline of Canada: Littoral Processes and Shore Morphology. Geol. Surv. Can., Pap. 80-10, pp. 70-88.

Inman, D.L. and Bagnold, R.A., 1963. Littoral processes. In: M.N. Hill (Editor), The Sea, Vol. 3. Wiley-Interscience, New York, N.Y., pp.529-533.

Inman, D.L. and Bowen, A.J., 1962, Flume experiments on sand transport by waves and currents. Proc. 8th Coastal Engineering Conf., Mexico City, pp.137-150.

Inman, D.L. and Frautschy, J.D., 1966. Littoral processes and the development of shorelines. Proc. Coastal Engineering Speciality Conf., Santa Barbara, Calif., pp.511-536.

Ippen, A.T. and Eagleson, P.S., 1955. A study of sediment sorting by waves shoaling on a plane beach. Beach Erosion Board, U.S. Army Corps of Engineers, Tech. Mem., 63, $83 \mathrm{pp}$.

Johnson, D.W., 1919. Shore processes and shoreline development. Columbia University, Facsimile Ed., Hafner, New York, N.Y., 1972, 584 pp.

Mittler, P.R., 1981. Storm related sediment flux and equilibrium in a barred nearshore, Kouchibouguac Bay, New Brunswick, Canada. Unpubl. Ph.D. Diss., University of Toronto, Scarborough, Ont., 419 pp. 